\title{
Two new species of oribatid mites of Lasiobelba (Acari, Oribatida, Oppiidae) from Nepal, including a key to all species of the genus
}

\author{
Sergey G. Ermilov', Umukusum Ya. Shtanchaeva², \\ Luis S. Subías ${ }^{2}$ Jochen Martens ${ }^{3}$
}

I Tyumen State University, Tyumen, Russia 2 Complutense University, Madrid, Spain 3 Johannes Gutenberg University, Mainz, Germany

Corresponding author: Sergey G. Ermilov (ermilovacari@yandex.ru)

Academic editor: Vladimir Pesic | Received 20 May 2014 | Accepted 20 June 2014 | Published 8 July 2014

http://zoobank.org/D34D9721-67A7-4334-8AA5-A3574FF54BCC

Citation: Ermilov SG, Shtanchaeva UYa, Subías LS, Martens J (2014) Two new species of oribatid mites of Lasiobelba (Acari, Oribatida, Oppiidae) from Nepal, including a key to all species of the genus. ZooKeys 424: 1-17. doi: 10.3897/ zookeys.424.7990

\begin{abstract}
Two new species of oribatid mites of the genus Lasiobelba (Oribatida, Oppiidae), Lasiobelba (Lasiobelba) daamsae sp. n. and Lasiobelba (Antennoppia) nepalica sp. n., are described from eastern Nepal. Lasiobelba (L.) daamsae sp. n. is most similar to $L$. (L.) remota Aoki, 1959 and $L$. (L.) gibbosa (Mahunka, 1985), however, it differs from both by the anterior part of pedotecta I specifically curved, rostrum pointed and exobothridial setae not shorter than bothridial setae. Lasiobelba (Antennoppia) nepalica sp. n. is most similar to L. (A.) granulata (Mahunka, 1986), however, it differs from the latter by the larger body size, exobothridial setae longer than rostral setae and bothridial setae not longer than interlamellar setae. An identification key to known species of Lasiobelba is given.
\end{abstract}

\section{Keywords}

Oribatid mites, new species, Lasiobelba, key, Nepal

Copyright Sergey G. Ermilov et al. This is an open access article distributed under the terms of the Creative Commons Attribution License (CC BY 4.0), which permits unrestricted use, distribution, and reproduction in any medium, provided the original author and source are credited. 


\section{Introduction}

Lasiobelba is a genus of oribatid mites (Oribatida, Oppiidae, Oppiinae) that was proposed by Aoki (1959) with Lasiobelba remota Aoki, 1959 as type species. The main generic characters (summarized by Aoki 1959; Subías and Balogh 1989; Ohkubo 2001; including our additions) are: costulae and transcostula absent; prodorsal setae well developed, setiform (exception: interlamellar setae represented by alveoli); bothridial setae spindle-form or setiform; notogaster with nine to 10 pairs of notogastral setae (setae $c$ reduced, minute or represented by alveoli); dorsal notogastral setae inserted in four subparallel rows, rarely in two parallel rows; genital plates with five pairs of genital setae; adanal lyrifissures located near to anal aperture.

Currently, Lasiobelba comprises two subgenera (Lasiobelba (Lasiobelba) Aoki, 1959, Lasiobelba (Antennoppia) Mahunka, 1983 - see Mahunka 1983a) and 32 species, which have a cosmopolitan distribution (Subías 2004, updated 2014). The subgenus Lasiobelba (Lasiobelba) differs from Lasiobelba (Antennoppia) by the morphology of bothridial setae (spindle-form versus setiform).

In the course of taxonomic identification of oribatid mites from Nepal ${ }^{1}$ (Ermilov et al. 2013, 2014; Ermilov and Martens 2014), we found two new species of the genus Lasiobelba; one belonging to Lasiobelba (Lasiobelba), other to Lasiobelba (Antennoppia). The first goal of our paper is to describe these species. The second goal of our paper is to present an identification key to all known species of Lasiobelba.

\section{Materials and methods}

Five specimens (holotype: male; four paratypes: all males) of Lasiobelba (Lasiobelba) daamsae sp. n. are from: eastern Nepal, $27^{\circ} 19^{\prime} \mathrm{N}, 87^{\circ} 78^{\prime} \mathrm{E}$, Panchthar District, upper course of Mai Majuwa river, pasture Dhorpar Kharka, soil in mixed broadleaved forest, 2770 m a.s.l., 27-28.VIII.1983, collected by J. Martens and B. Daams. Four specimens (holotype: male; three paratypes: two males and one female) of Lasiobelba (Antennoppia) nepalica sp. n. are from: eastern Nepal, $26^{\circ} 99^{\prime} \mathrm{N}, 86^{\circ} 67^{\prime} \mathrm{E}$, Ilam District, soil in remnants of broadleaved forest with plantations of Cryptomeria japonica, $2100 \mathrm{~m}$ a.s.1., 31.III.-01.IV.1980, collected by J. Martens and A. Ausobsky.

Holotypes and paratypes were mounted in lactic acid on temporary cavity slides for measurement and illustration. The body length was measured in lateral view, from the tip of the rostrum to the posterior edge of the ventral plate. The notogastral width refers to the maximum width in dorsal aspect. Lengths of body setae were measured in lateral aspect. All body measurements are presented in micrometers. Formula for leg setation is given in parentheses according to the sequence trochanter-femur-genutibia-tarsus (famulus included). Formula for leg solenidia is given in square brackets according to the sequence genu-tibia-tarsus. General terminology used in this paper follows that of Norton and Behan-Pelletier (2009).

Results of the Himalaya Expeditions $(1980,1983)$ of Dr. Jochen Martens. 


\section{Taxonomy}

Description of Lasiobelba (Lasiobelba) daamsae sp. $\mathbf{n}$. http://zoobank.org/EE1BC06A-8B49-4004-B3EA-D1FF46336897 Figs 1-9

Diagnosis. Body size: $1278-1310 \times 747-863$. Rostrum pointed. Prodorsal setae long, barbed; in $\approx l e>s s \approx e x>r o$. Bothridial setae spindle-form, with long, thin apex, barbed. Nine pairs of notogastral setae long, barbed $\left(p_{1}-p_{3}\right.$ shorter than others). Antero-medial part of rutelli with tooth. Anterior part of pedotecta I specifically curved. Anogenital setae barbed. Dorsal side of leg claws with small teeth.

Description. Measurements. Body length: 1294 (holotype, male), 1278-1310 (four paratypes: males); notogaster width: 796 (holotype), 747-863 (four paratypes).

Integument (Figs 1, 3). Body color light brownish. Body surface smooth, but lateral parts of prodorsum with microgranulate cerotegument (diameter granules less than 1).

Prodorsum (Figs 1-3). Rostrum with conical tooth (tr, 12-16). A row, comprising several muscle sigillae, is located in front of the bothridia (usually very poorly visible). Muscle sigilla in interbothridial region absent, but one pair of longitudinal, dark brown structures are present. Rostral (ro, 199-232), lamellar (le, 365-381), interlamellar (in, 365-381) and exobothridial (ex, 265-298) setae well developed, setiform, barbed. Bothridial setae (ss, 265-298) spindle-form, barbed, with weakly developed elongate head and long, thin apex. A pair of triangular tubercles $(t b)$ located posteriorly to bothridia.

Notogaster (Figs 1-3). Anterior border convex. Notogastral setae $c$ represented by alveolus. Nine other pairs of notogastral setae long, barbed; $p_{1}-p_{3}(215-249)$ shorter than others (431-481). Lyrifissures ia poorly visible, im, ip, ih, ips and opisthonotal gland openings present, but visible under high magnification in dissected specimens.

Gnathosoma (Figs 2, 4, 5). Subcapitulum longer than wide (298-315 × 199-215). Antero-medial part of rutelli with tooth $(t s, 8)$. Subcapitular setae setiform, barbed; $a$ (66-83) shorter than $m$ and $h$ (both 116-132). Two pairs of adoral setae (or, or, 33-49)

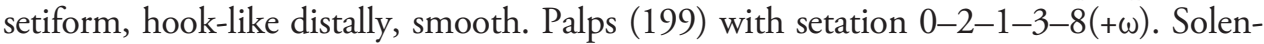
idion thickened, blunt-ended, pressed to the palptarsus surface in basal part and distal seta in distal part. Chelicerae (298-315) with two barbed setae; cha (99) longer than chb (66). One short tooth (4-6) located posteriorly to seta cha. Trägårdh's organ distinct.

Epimeral and lateral podosomal regions (Figs 1-3). Apodemes (1, 2, sejugal, 4) weakly developed. Epimeral setae setiform, barbed; setae $1 a, 2 a, 3 a$ (83-99) shorter than $1 b$, $1 c, 3 b, 4 a, 4 b$ (149-166) and 3c, 4c (199-232). Anterior part of pedotecta I (Pd I) elongate and specifically curved, forming a tooth $(t p d)$. Discidia (dis) triangular, pointed.

Anogenital region (Figs 2, 3). Five pairs of genital $\left(g_{1}-g_{3}, 74-83 ; g_{4}, g_{5}, 108-116\right)$, one pair of aggenital (ag, 166-199), three pairs of adanal $\left(a d_{1}-a d_{3}, 166-199\right)$ and two pairs of anal $\left(a n_{1}, a n_{2}, 149-166\right)$ setae setiform, barbed. Distance between setae $a d_{3}-$ $a d_{3}$ longer than $a d_{2}-a d_{2}$ and $a d_{1}-a d_{1}$. Adanal lyrifissures iad located diagonally, but very close to anal aperture. 


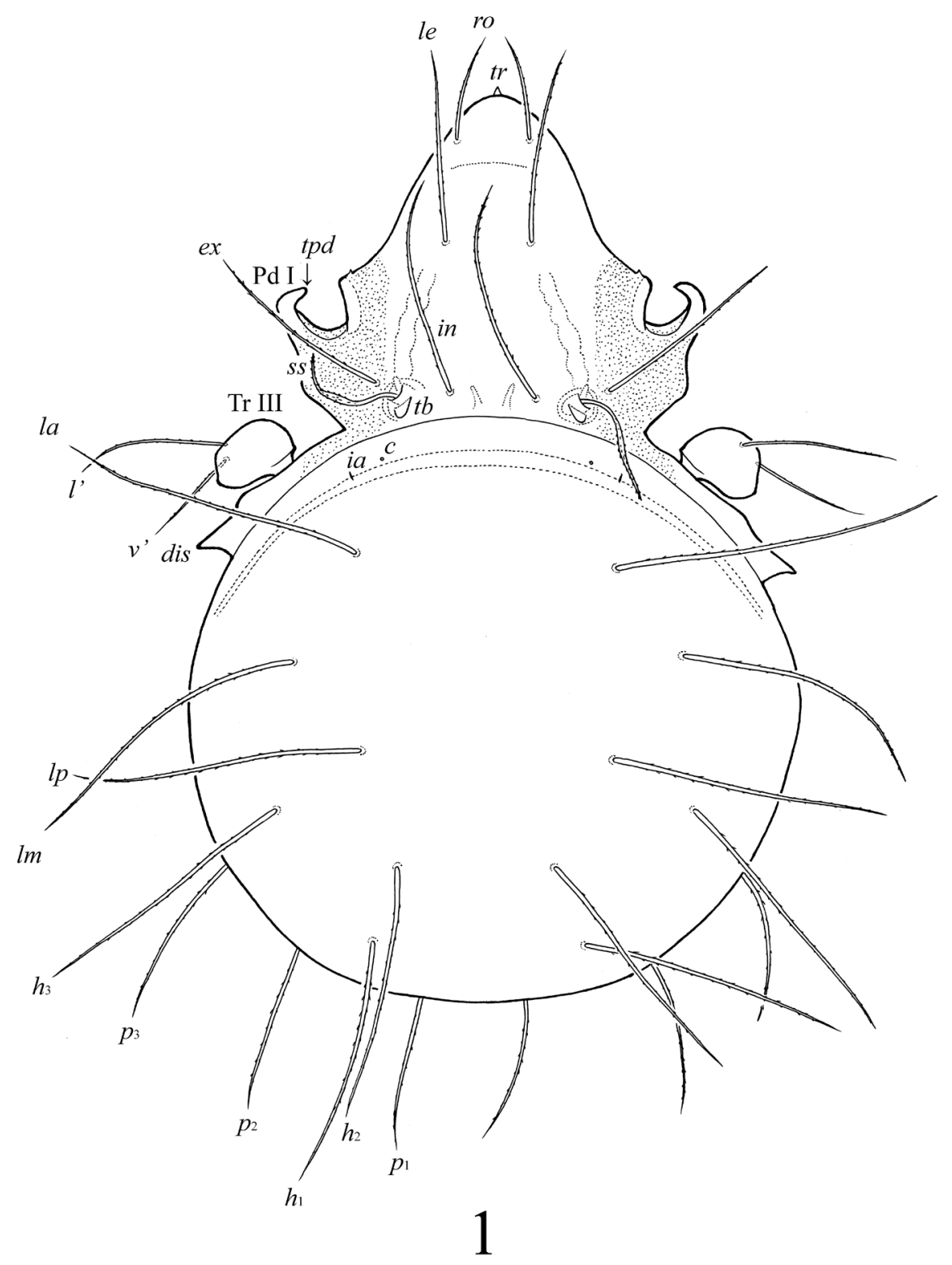

Figure I. Lasiobelba (Lasiobelba) daamsae sp. n.: dorsal view (legs except trochanters III not illustrated). Scale bar $400 \mu \mathrm{m}$.

Legs (Figs 1, 6-9). Generally, morphology typical for species of Lasiobelba (Bernini 1973; Ohkubo 2001; Ermilov and Kalúz 2012). Dorsal side of each claw in all tarsi with two rows of small teeth $(t)$. Formulae of leg setation and solenidia: I (1-5-2-420) [1-2-2], II (1-5-2-4-16) [1-1-2], III (2-3-1-3-15) [1-1-0], IV (1-2-2-3-12) [0-1-0]; homology of setae and solenidia indicated in Table 1 . Setae $p$ setiform on 

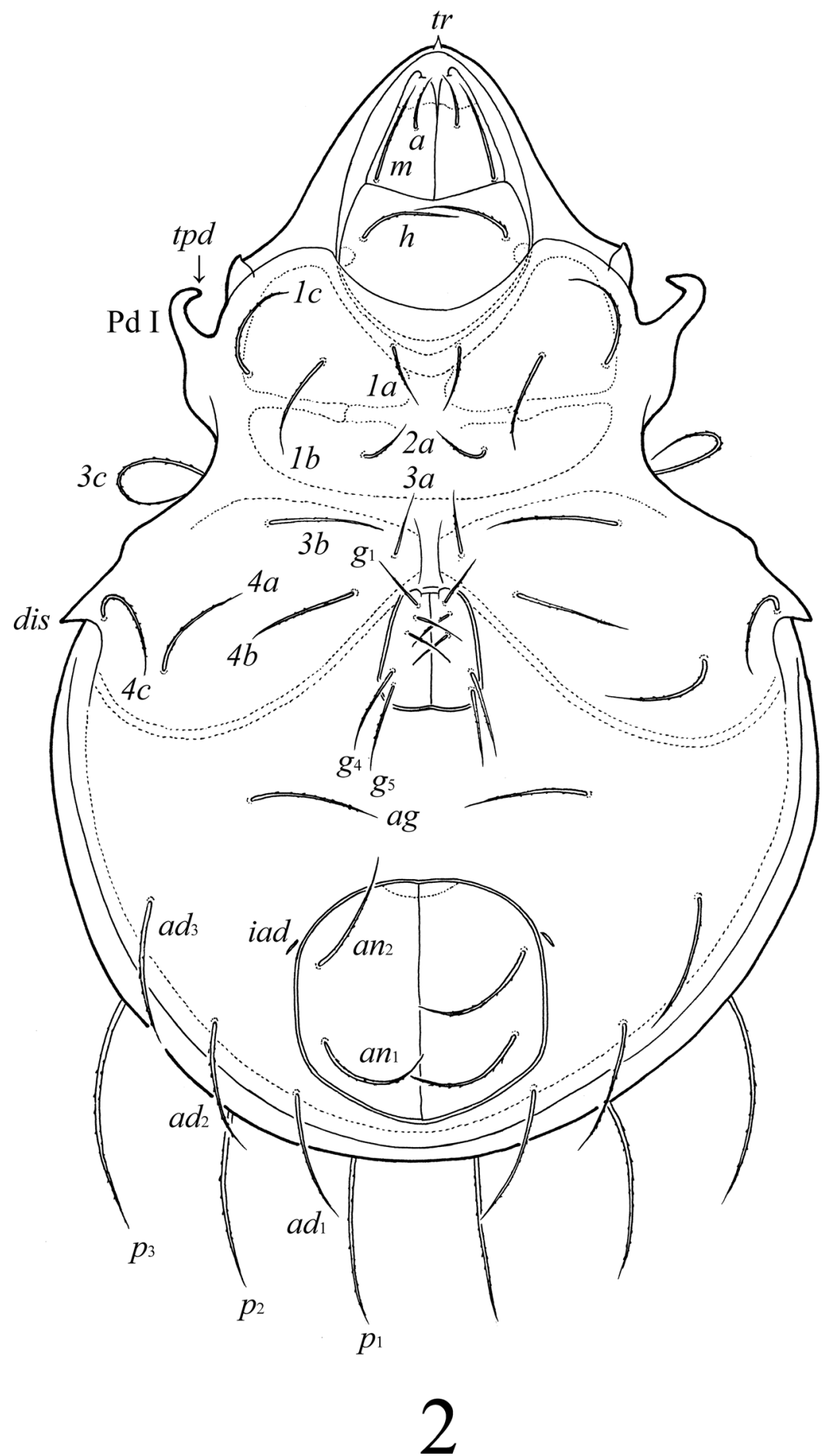

Figure 2. Lasiobelba (Lasiobelba) daamsae sp. n.: ventral view (legs not illustrated). Scale bar $400 \mu \mathrm{m}$. 

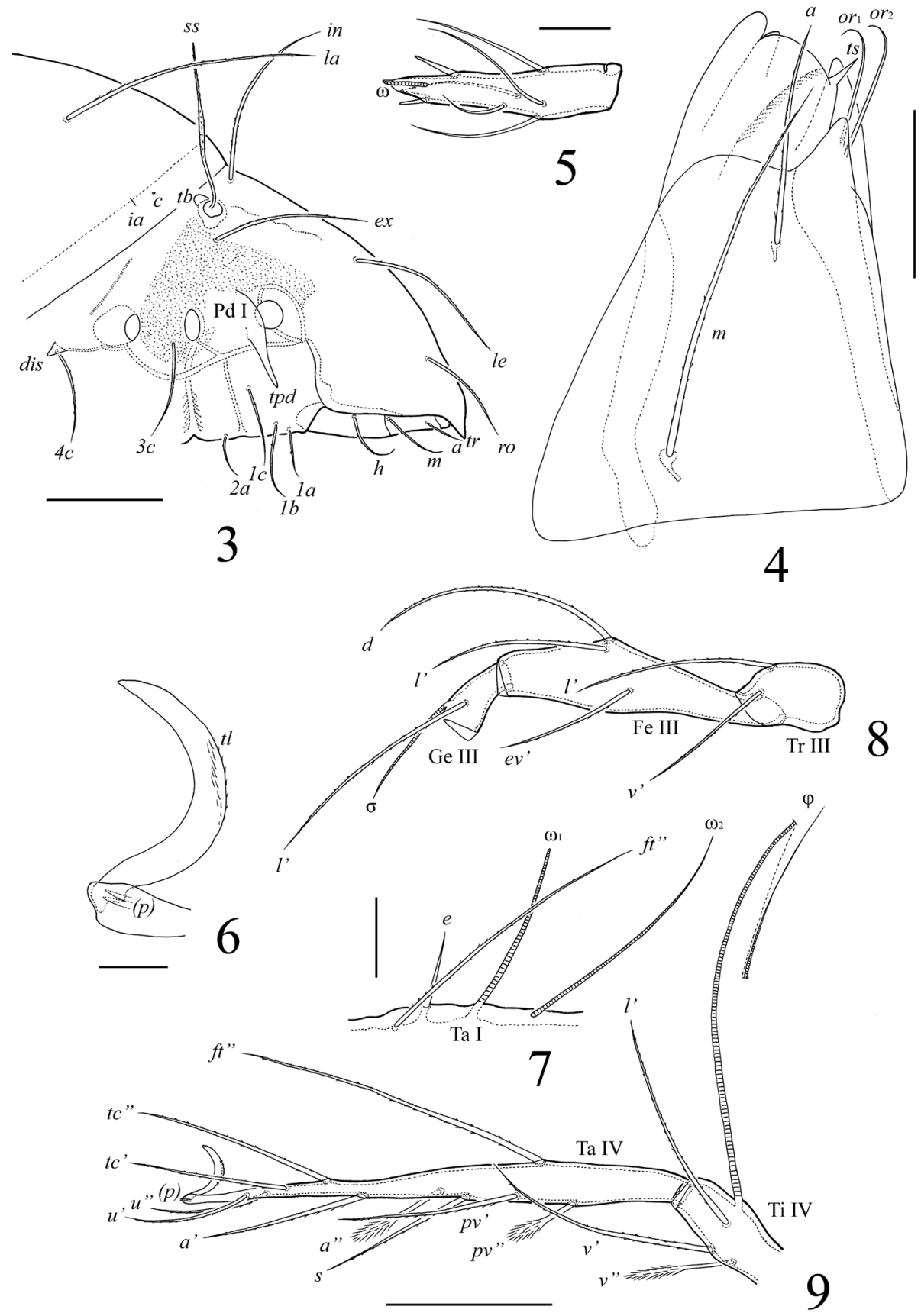

Figures 3-9. Lasiobelba (Lasiobelba) daamsae sp. n.: 3 lateral view of prodorsum (legs not illustrated) and anterior part of notogaster $\mathbf{4}$ right rutellum and gena of subcapitulum, ventral view $\mathbf{5}$ palptarsus $\mathbf{6}$ leg claw II and setae $p \mathbf{7}$ localization of solenidia, famulus and seta $f t$ " on tarsus I, right, antiaxial view $\mathbf{8}$ trochanter, femur and genu of leg III, right, antiaxial view 9 tarsus and anterior part of tibia of leg IV, right, antiaxial view. Scale bars $200 \mu \mathrm{m}(\mathbf{3}, \mathbf{8}, \mathbf{9}), 50 \mu \mathrm{m}(\mathbf{4}, \mathbf{7}), 20 \mu \mathrm{m}(\mathbf{5 , 6})$. 
Table I. Leg setation and solenidia of Lasiobelba (Lasiobelba) daamsae sp. n. (same data for Lasiobelba (Antennoppia) nepalica sp. n.).

\begin{tabular}{l|l|l|l|l|l}
\hline Leg & Trochanter & Femur & Genu & Tibia & Tarsus \\
\hline I & $v^{\prime}$ & $d,(l), b v^{\prime \prime}, v^{\prime \prime}$ & $(l), \sigma$ & $(l),(v), \varphi_{1}, \varphi_{2}$ & $(f t),(t c),(i t),(p),(u),(a), s,(p v), v^{\prime},(p l), l^{\prime \prime}, \varepsilon, \omega_{1}, \omega_{2}$ \\
\hline II & $v^{\prime}$ & $d,(l), b v^{\prime \prime}, v^{\prime \prime}$ & $(l), \sigma$ & $(l),(v), \varphi$ & $(f t),(t c),(i t),(p),(u),(a), s,(p v), l^{\prime \prime}, \omega_{\mathbf{1}}, \omega_{2}$ \\
\hline III & $l^{\prime}, v^{\prime}$ & $d, l^{\prime}, e v^{\prime}$ & $l^{\prime}, \sigma$ & $l^{\prime},(v), \varphi$ & $(f t),(t c),(i t),(p),(u),(a), s,(p v)$ \\
\hline IV & $v^{\prime}$ & $d, e v^{\prime}$ & $d, l^{\prime}$ & $l^{\prime},(v), \varphi$ & $f t^{\prime \prime},(t c),(p),(u),(a), s,(p v)$ \\
\hline
\end{tabular}

Roman letters refer to normal setae ( $\varepsilon$ to famulus), Greek letters to solenidia. Single prime () marks setae on anterior and double prime (") setae on posterior side of the given leg segment. Parentheses refer to a pair of setae.

tarsi I, very short, conical on tarsi II-IV. Famulus $(\varepsilon)$ setiform, straight, pointed, inserted posteriorly to solenidion $\omega_{1}$.

Type deposition. The holotype and one paratype are deposited in the collection of the Senckenberg Institution Frankfurt, Germany; three paratypes are deposited in the collection of the Tyumen State University Museum of Zoology, Tyumen, Russia.

Etymology. The specific name is dedicated to Mrs. Beate Daams for her assistance in Nepalese scientific researches.

Remarks. In having the long notogastral setae, large body size and spindle-form bothridial setae, Lasiobelba (Lasiobelba) daamsae sp. n. is most similar to L. (L.) remota Aoki, 1959 from the Oriental and Palaearctic regions and Lasiobelba (Lasiobelba) gibbosa (Mahun$\mathrm{ka}, 1985)$ from the Ethiopian region. However, it differs from both by the anterior part of pedotecta I specifically curved (versus straight in $L$. (L.) remota and $L$. (L.) gibbosa), rostrum pointed (versus rounded in $L .(L$.$) remota and nasiform in L .(L$.$) gibbosa) and exobothridial$ setae not shorter than bothridial setae (versus shorter in $L$. (L.) remota and L. (L.) gibbosa).

\section{Description of Lasiobelba (Antennoppia) nepalica sp. n.} http://zoobank.org/F023D27B-A28D-4A1F-B987-3834F4DF4E97 Figs $10-15$

Diagnosis. Body size: 996-1278 $\times 697-830$. Prodorsal setae long, barbed; $s s \approx$ in $>$ $l e>e x>$ ro. Nine pairs of notogastral setae long, barbed ( $p_{1}-p_{3}$ shorter than others). Antero-medial part of rutelli with tooth. Anogenital setae barbed. Dorsal side of leg claws with small teeth.

Description. Measurements. Body length: 1195 (holotype, male), 996-1278 (three paratypes: two males and one female); notogaster width: 730 (holotype), 697-830 (three paratypes).

Integument (Figs 10, 12). Body color light brownish. Body surface smooth, but lateral parts of prodorsum with microgranulate cerotegument (diameter granules up to 1 ).

Prodorsum (Figs 10, 12). Rostrum widely or narrowly rounded. A row, comprising several muscle sigillae, is located in front of the bothridia. One pair of muscle sigilla in 


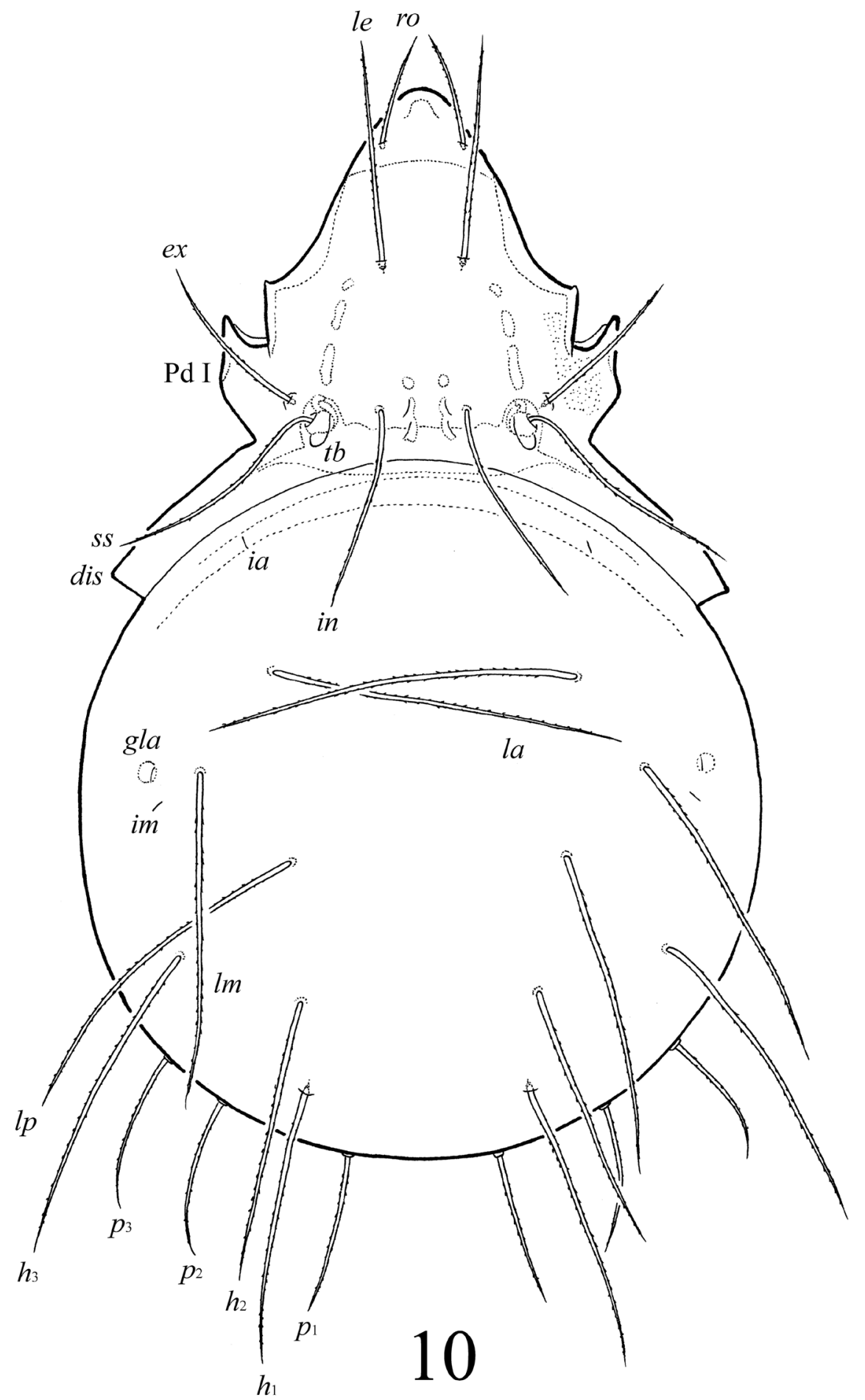

Figure 10. Lasiobelba (Antennoppia) nepalica sp. n.: dorsal view (legs not illustrated). Scale bar $400 \mu \mathrm{m}$. 


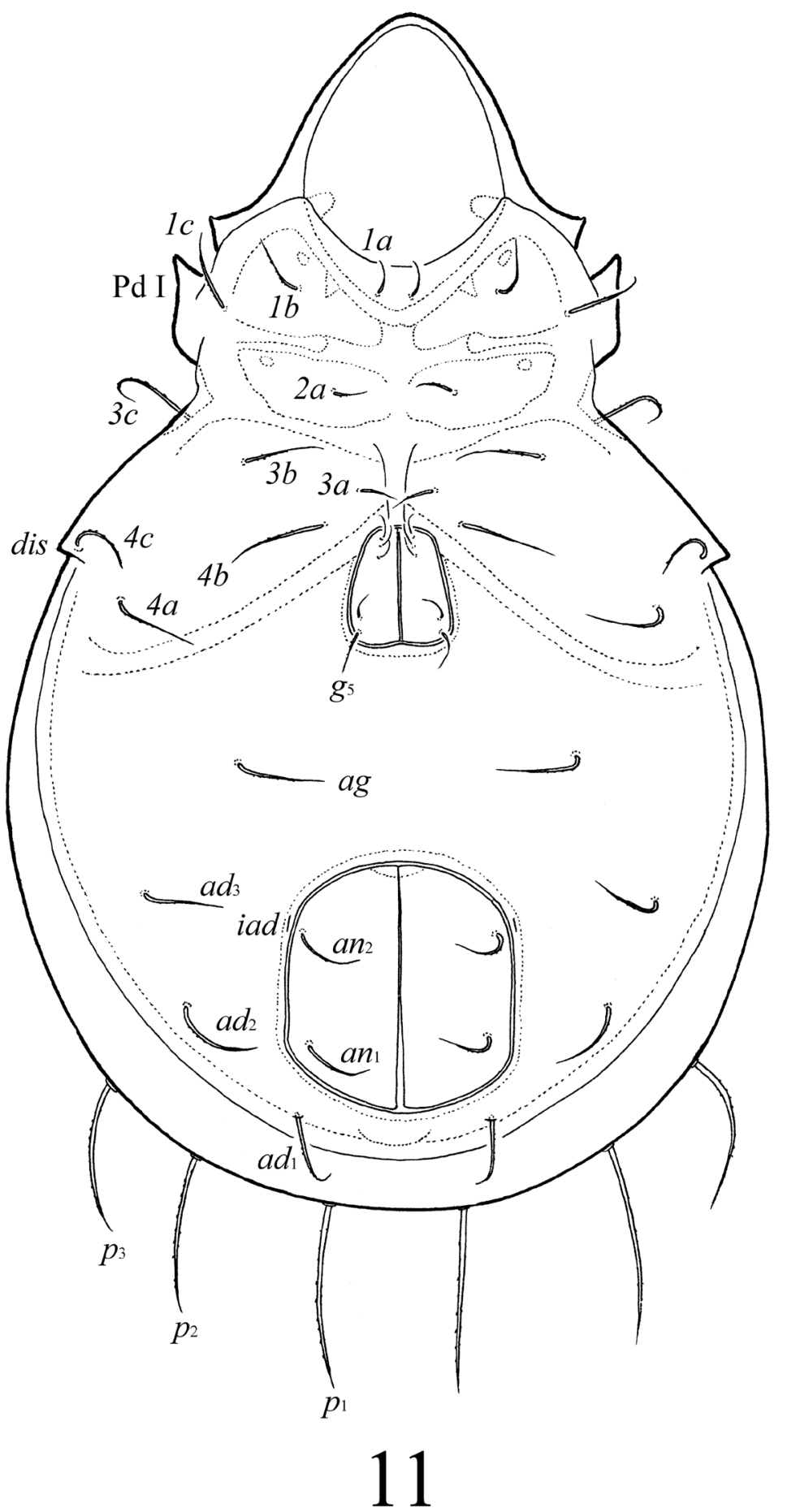

Figure II. Lasiobelba (Antennoppia) nepalica sp. n.: ventral view (gnathosoma and legs not illustrated). Scale bar $400 \mu \mathrm{m}$. 

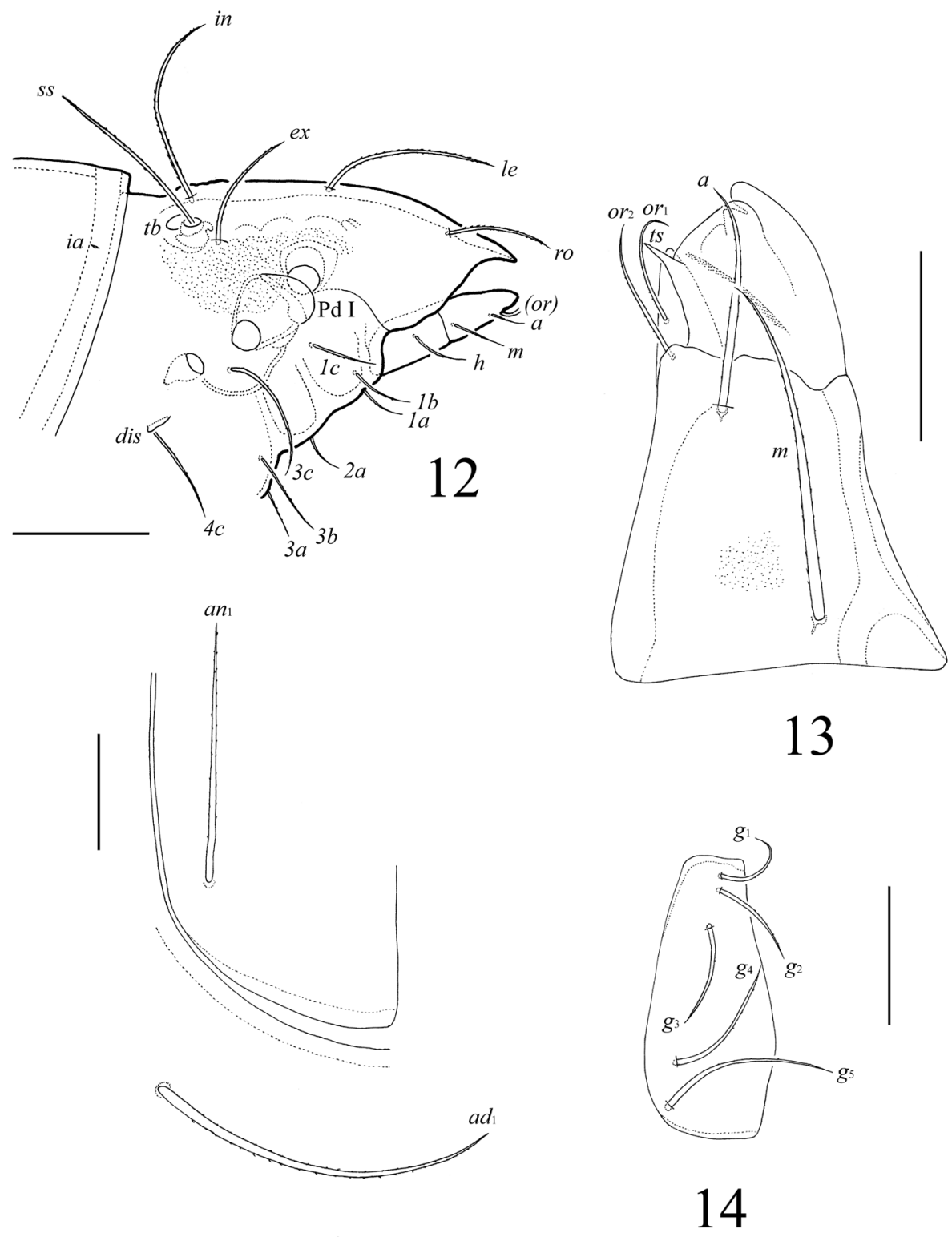

\section{5}

Figures I2-I5. Lasiobelba (Antennoppia) nepalica sp. n.: 12 lateral view of prodorsum (legs not illustrated) and anterior part of notogaster $\mathbf{I} \mathbf{3}$ left rutellum and gena of subcapitulum, ventral view $\mathbf{1} \mathbf{4}$ genital plate, right $\mathbf{I} \mathbf{5}$ posterior part of anal plate with seta $a n_{1}$ and adanal seta $a d_{1}$. Scale bar $50 \mu \mathrm{m}$.

interbothridial region poorly visible. Rostral (143-164), lamellar (254-287), interlamellar (307-348), exobothridial (205-258) and bothridial (307-348) setae well developed, setiform, barbed. A pair of triangular tubercles located posteriorly to bothridia. 
Notogaster (Figs 10-12). Anterior border convex. Notogastral setae $c$ and their alveoli reduced. Nine pairs of notogastral setae long, barbed; $p_{1}-p_{3}(184-192)$ shorter than $h_{1}, h_{2}(265-332)$ and others (398-464). Lyrifissures $i a$, im and opisthonotal gland openings ( $g l a)$ poorly visible; lyrifissures ip, ih, ips present, but visible under high magnification in dissected specimens.

Gnathosoma (Figs 12, 13). Subcapitulum longer than wide $(266 \times 199-209)$. Antero-medial part of rutelli with tooth (8-10). Subcapitular setae setiform, barbed; $a$ (61-65) shorter than $m$ and $h$ (both 98-102). Two pairs of adoral setae (41-45) setiform, indistinctly smooth. Palps (196) with setation $0-2-1-3-8(+\omega)$. Solenidion thickened, blunt-ended, pressed to the palptarsus surface in basal part and distal seta in distal part. Chelicerae (266) with two barbed setae; cha (86) longer than $c h b$ (53). One short tooth (4-6) located posteriorly to seta $c h a$. Trägårdh's organ distinct.

Epimeral and lateral podosomal regions (Figs 10-12). Apodemes (1, 2, sejugal, 4) weakly developed. Epimeral setae setiform, barbed; setae $1 a, 2 a$, 3a (69-86) shorter than $1 b, 1 c, 3 b, 4 a, 4 b$ (114-127), $3 c(205-209)$ and $4 c(155-164)$. Pedotecta I normally developed, scale-like. Discidia triangular, pointed.

Anogenital region (Figs $11,14,15)$. Five pairs of genital setae $\left(g_{1}-g_{3}, 41-53 ; g_{4}, 61-\right.$ $\left.69, g_{5}, 73-82\right)$ setiform, indistinctly barbed. One pair of aggenital (123-135), three pairs of adanal (159-172) and two pairs of anal (114-123) setae setiform, barbed. Distance between setae $a d_{3}-a d_{3}$ longer than $a d_{2}-a d_{2}$ and $a d_{1}-a d_{1}$. Adanal lyrifissures iad located longitudinally.

Legs. Generally, similar to Lasiobelba (Lasiobelba) daamsae sp. n. (see also Table 1).

Type deposition. The holotype and one paratype are deposited in the collection of the Senckenberg Institution Frankfurt, Germany; two paratypes are deposited in the collection of the Tyumen State University Museum of Zoology, Tyumen, Russia.

Etymology. The specific name "nepalica" refers to the country origin, Nepal.

Remarks. In having the long prodorsal and notogastral setae and large body size, Lasiobelba (Antennoppia) nepalica sp. n. is most similar to L. (A.) granulata (Mahunka, 1986) from Tanzania. However, it clearly differs from the latter by the larger body size (996-1278 × 697-830 versus 820-861 × 541-574 in L. (A.) granulata), exobothridial setae longer than rostral setae (versus rostral longer in $L$. (A.) granulata) and bothridial setae not longer than interlamellar setae (versus clearly longer in $L$. (A.) granulata).

\section{Key to known species of Lasiobelba ${ }^{2}$}

1 Bothridial setae spindle-form 2, subgenus Lasiobelba (Lasiobelba)

- $\quad$ Bothridial setae setiform ............. 18, subgenus Lasiobelba 18, subgenus Lasiobelba (Antennoppia) 3

- Dorsal notogastral setae of medium size or short, $l m$ not reaching the insertions of $l p$

Lasiobelba (Antennoppia) rigida was very poorly described by Ewing (1909), therefore we did not include this species in the key. 
Notogastral setae $l a, l m, l p$ longer than bothridial setae............................... 4

Notogastral setae $l a, l m$, $l p$ shorter than bothridial setae.............................10

Rostrum widely or narrowly rounded, or truncated

Anterior part of pedotecta I specifically curved; notogastral setae $p_{1}-p_{3}$ longer than adanal setae; body size: $1278-1310 \times 747-863$

Lasiobelba (Lasiobelba) daamsae sp. n. Distribution: Nepal

Pedotecta I normally developed; notogastral setae $p_{1}-p_{3}$ shorter than adanal setae; body size: $772-891 \times 410-456$.

Lasiobelba (Lasiobelba) gibbosa (Mahunka, 1985). Distribution: Ethiopian region

Interlamellar setae similar in length (little longer or shorter) to bothridial setae.

Interlamellar setae clearly shorter than bothridial setae................................9

Rostrum truncated; body size: 794-834 × 492-564

Lasiobelba (Lasiobelba) insulata Ohkubo, 2001. Distribution: Japan

Rostrum widely or narrowly rounded

Rostrum widely rounded; notogastral setae $p_{1}-p_{3}$ inserted close to each other; body size: $560 \times 330$

..... Lasiobelba (Lasiobelba) subuligera (Berlese, 1916) (see also Mahunka and Mahunka-Papp 1995). Distribution: Argentina

Rostrum with protruding ledge; notogastral setae $p_{1}-p_{3}$ clearly distanced from each other; body size: 940-1030 × 620-650

Lasiobelba (Lasiobelba) remota Aoki, 1959. Distribution: Palaearctic and Oriental regions

Bothridial setae with head without long apex; interbothridial region with two pairs of muscle sigilla; body size: $950 \times 630$

Lasiobelba (Lasiobelba) suchetae Sanyal, 1992. Distribution: India Bothridial setae with long, thin apex; interbothridial region without muscle sigilla; body size: 625-684 × 388-437Lasiobelba (Lasiobelba) vietnamica Balogh, 1983 (see Balogh and Mahunka 1967). Distribution: Vietnam Notogastral setae $c$ short, present

Notogastral setae $c$ represented by alveoli

11 Anterior part of notogaster smooth; epimeral setae $1 a, 2 a, 3 a$ thin, almost smooth; body size: $478-522 \times 277-315$

..Lasiobelba (Lasiobelba) lemurica Mahunka, 1997. Distribution: Madagascar Anterior part of notogaster microfoveolate; epimeral setae $1 a, 2 a, 3 a$ heavily barbed; body size: $566 \times 307$

.Lasiobelba (Lasiobelba) pontica Vasiliu \& Ivan, 2011. Distribution: Romania

12 Body surface of notogaster with longitudinal ridges; interbothridial region with one pair of tubercles; body size: $693 \times 455$

...Lasiobelba (Lasiobelba) sculptra Wang, 1993. Distribution: southern China Body surface of notogaster granulate; interbothridial region without tubercles; body size: $610-644 \times 386-402$

..Lasiobelba (Lasiobelba) yunanensis Wen, 1999. Distribution: southern China 
$13 \quad$ Notogastral setae $c$ represented by alveoli .........................................14

Notogastral setae $c$ short, present ...........................................................15

14 Notogastral setae smooth; body length: 468 .......... Lasiobelba (Lasiobelba) hespiridiana (Pérez-Ínigo, 1986). Distribution: Mediterranean Notogastral setae barbed; body size: 787-825 × 495-539.... Lasiobelba (Lasiobelba) rubida (Wallwork, 1977). Distribution: Santa Helena Islands 15 Interlamellar setae shorter than lamellar setae; body size: 413-600 × 228336........ Lasiobelba (Lasiobelba) pori (Vasiliu \& Ivan, 1995) (=Lasiobelba arabica Mahunka, 2000, =Lasiobelba (Lasiobelba) neonominata Subías, 2004 (see Kok 1967) ${ }^{3}$. Distribution: Ethiopian and Palaearctic regions, Hawai

16 Rostrum tripartite; interbothridial region with three pairs of muscle sigilla; body size: $500-540 \times 253$

Lasiobelba (Lasiobelba) decui (Vasiliu et Ivan, 1995). Distribution: Israel Rostrum rounded; interbothridial region with two pairs of muscle sigilla . 17 17 Bothridial setae with numerous barbs; notogastral setae $p_{3}$ longer than $p_{1}$ and $p_{2}$; body size: $400-530 \times 215-280$. Lasiobelba (Lasiobelba) arcidiaconoae (Bernini, 1973). Distribution: Mediterranean, India

- $\quad$ Bothridial setae with several short barbs; notogastral setae $p_{3}$ similar in length to $p_{1}$ and $p_{2}$; body size: $313 \times 233 \ldots \ldots \ldots .$. Lasiobelba (Lasiobelba) kuehnelti (Csiszár, 1961). Distribution: Oriental, Australian and Ethiopian regions

18 Heterotrichy of dorsal notogastral setae well developed, $l a$ and $l m$ considerably longer than $l p$

- $\quad$ Heterotrichy of dorsal notogastral setae absent or weakly expressed, la and $l m$ not longer than $l p$ 20 Notogastral setae la long, reaching the insertions of $l p$; lamellar setae longer than rostral setae; body size: $456 \times 216$. Lasiobelba (Antennoppia) quadrisetosa Subías, 1989 - see Subías and Balogh 1989 (see also Mahunka 2001). Distribution: Greece

- $\quad$ Notogastral setae $l a$ of medium size, not reaching the insertions of $l p$; lamellar setae shorter than rostral setae; body size: 498-547 × 298-332 ... Lasiobelba (Antennoppia) chistyakovi Ermilov \& Kalúz, 2012. Distribution: Ecuador 20 Dorsal notogastral setae long, $l m$ reaching the insertions of $l p$. 21 Dorsal notogastral setae of medium size or short, $l m$ not reaching the insertions of $l p$

21 Notogastral setae $l a, l m$, $l p$ longer or similar in length to bothridial setae.....22 Notogastral setae $l a, l m$, lp shorter than bothridial setae.

22 Apodemes IV absent; adanal lyrifissures located diagonally to anal aperture; body size: $745 \times 510$

... Lasiobelba (Antennoppia) insignis Balogh, 1970. Distribution: New Guinea

Lasiobelba (Lasiobelba) pori, L. (L.) arabica and L. (L.) neonominata Subías, 2004 (=Oppia yodai africana Kok, 1967 "nom. praeoc." by Evans, 1953) morphologically are very similar among themselves. We have found any significant morphological differences. Hence, we suggest that $L$. $(L$. arabica and $L$. (L.) neonominata Subías, 2004 are junior subjective synonyms of $L$. (L.) pori. 
Apodemes IV present; adanal lyrifissures located longitudinally to anal aperture....

Bothridial setae smooth; body size: $590 \times 330$.

... Lasiobelba (Antennoppia) subnitida (Sellnick, 1924). Distribution: Brazil

24 Exobothridial setae longer than rostral setae; bothridial setae similar in length to interlamellar setae; body size: 996-1278 × 697-830

Lasiobelba (Antennoppia) nepalica sp. n. Distribution: Nepal Exobothridial setae shorter than rostral setae; bothridial setae longer than interlamellar setae; body size: $820-861 \times 541-574$

Lasiobelba

(Antennoppia) granulata (Mahunka, 1986). Distribution: Tanzania

Rostrum pointed; body size: 715-800 × 448-486 ....Lasiobelba (Antennoppia) major (Mahunka, 1983), see Mahunka 1983a. Distribution: Tanzania

Interlamellar setae represented by alveoli; body size: 590-623 × 232-250 ....

......Lasiobelba (Antennoppia) trichoseta (Mahunka, 1983), see Mahunka 1983b. Distribution: Tanzania

- Interlamellar setae well developed

27 Dorsal notogastral setae inserted in four subparallel rows; interbothridial region with one pair of triangular ridges; body size: 810-1180 × 510-526

.. Lasiobelba (Antennoppia) yoshii (Mahunka, 1987). Distribution: Borneo Dorsal notogastral setae inserted in two parallel rows; interbothridial region without triangular ridges.

Interlamellar setae longer than lamellar setae; interbothridial region with three pairs of muscle sigilla; body size: $740 \times 450$

Lasiobelba (Antennoppia) capilligera (Berlese, 1916) (see also Mahunka 1991). Distribution: Ethiopian region

- Interlamellar setae slightly shorter than lamellar setae; interbothridial region without muscle sigilla; body size: 555-652 × 314-367 ....Lasiobelba (Antennoppia) minor (Mahunka, 1983), see Mahunka 1983a. Distribution: Tanzania

29 Notogastral setae $c$ represented by alveoli; rostrum with protruding ledge; body size: 565-605 × 315-335 ....... Lasiobelba (Antennoppia) ultraciliata (Jacot, 1934). Distribution: Australian region

- $\quad$ Notogastral setae $c$ short, present; rostrum rounded, without protruding ledge.

30 Interlamellar setae similar in length to lamellar setae; exobothridial setae similar in length to rostral setae, respectively; body size: $347 \times 185 \ldots$ Lasiobelba (Antennoppia) heterosa (Wallwork, 1964). Distribution: Ethiopian and Palaearctic regions

- Interlamellar setae longer than lamellar setae; exobothridial setae shorter than rostral setae; body size: $525-637 \times 288-337$. Lasiobelba (Antennoppia) izquierdoae Arillo, Gil-Martin \& Subías, 1994. Distribution: Canary Islands 


\section{Acknowledgements}

The authors are thankful to two anonymous reviewers for valuable comments on the manuscript J. Martens thanks B. Daams and A. Ausobsky for helpful companionship during the Nepalese expeditions, as well as the Feldbausch Foundation and the Wagner foundation at Fachbereich Biologie of Mainz University for over the years many annual grants to carry out field work in Asia.

\section{References}

Arillo A, Gil-Martin J, Subías LS (1994) Oribatidos del "M.S.S." de las Islas Canarias. Poroscheloribatinae subfam. n. (Acari, Oribatida). Mém. Biospéol. 21: 1-6.

Aoki J (1959) Die moosmilben (Oribatei) aus Südjapan. Bulletin of the Biogeographical Society of Japan 21(1): 1-22.

Balogh J (1970) New oribatids (Acari) from New Guinea. II. Acta Zoologica Academiae Scientiarum Hungaricae 16(3-4): 291-344.

Balogh J (1983) A partial revision of the Oppiidae Grandjean, 1954 (Acari: Oribatei). Acta Zoologica Academiae Scientiarum Hungaricae 29(1-3): 1-79.

Balogh J, Mahunka S (1967) New oribatids (Acari) from Vietnam. Acta Zoologica Academiae Scientiarum Hungaricae 13(1-2): 39-74.

Berlese A (1916) Centuria terza di Acari nuovi. Redia 12: 289-338.

Bernini F (1973) Notulae oribatologicae VII. Gli Oribatei (Acarida) dell'isolotto di Basiluzzo (Isole Eolie). Lav. Del. Soc. Ital. Biogeogr., Nuov. Ser. 3: 355-480.

Csiszár MJ (1961) New oribatids from Indonesian soils (Acari). Acta Zoologica Academiae Scientiarum Hungaricae 7(3-4): 345-366.

Ermilov SG, Kalúz S (2012) Two new species of Oppiidae (Acari: Oribatida) from Ecuador. International Journal of Acarology 38(6): 521-527. doi: 10.1080/01647954.2012.687499

Ermilov SG, Kalúz S, Martens S (2014) Additions to the Indian oribatid mite fauna, with description of a new species of the genus Niphocepheus (Acari, Oribatida). Systematic \& Applied Acarology 19(1): 58-66. doi: 10.11158/saa.19.1.4

Ermilov SG, Martens J (2014) Additions to the Nepalese oribatid mite fauna, with description of two new species (Acari, Oribatida). International Journal of Acarology 40(2): 123-132. doi: 10.1080/01647954.2013.870227

Ermilov SG, Martens J, Tolstikov AV (2013) New species of oribatid mites of the genera Lepidozetes and Scutozetes (Acari, Oribatida, Tegoribatidae) from Nepal. ZooKeys 339: 55-65. doi: 10.3897/zookeys.339.6199

Ewing HE (1909) New American Oribatoidea. Journal of the New York Entomological Society 17(3): 116-136.

Jacot AP (1934) Some Hawaiian Oribatoidea (Acarina). Bernice P. Bishop Museum bulletin, Honolulu, 121: 1-99. 
Kok DJ (1967) Studies on some South African Oppiidae Grandjean, 1953 (Acarina: Oribatei).

The Journal of the Entomological Society of Southern Africa 30(1): 40-74.

Mahunka S (1983a) Oribatids from the eastern part of the Ethiopian region. II. Acta Zoologica Academiae Scientiarum Hungaricae 29(1-3): 151-180.

Mahunka S (1983b) Oribatids from the Eastern Part of the Ethiopian Region (Acari) III. Acta Zoologica Academiae Scientiarum Hungaricae 29(4): 397-440.

Mahunka S (1985) Description and redescription of Ethiopian oribatids (Acari, Oribatida), II. Annales Historico-Naturales Musei Nationalis Hungarici 77: 233-249.

Mahunka S (1986) Oribatids from Africa (Acari: Oribatida) III. Folia Entomologica Hungarica 47(1-2): 41-76.

Mahunka S (1987) Neue und interessante Milben aus dem Genfer Museum LV. Oribatids from Sabah (East Malaysia) I (Acari: Oribatida). Archives des Sciences 40(3): 292-305.

Mahunka S (1991) Notes, additions and redescriptions of the oribatid species of Berlese (Acari). Acta Zoologica Academiae Scientiarum Hungaricae 37(1-2): 27-58.

Mahunka S (1997) Oribatids from Madagascar III (Acari: Oribatida) (Acarologica Genavensia LXXXIII). Revue suisse de zoologie 104(1): 115-170.

Mahunka S (2000) Some oribatid mites from Yemen (Acari: Oribatida) (Acarologica Genavensia LXXXVIII). Annales Historico-Naturales Musei Nationalis Hungarici 92: 325-346.

Mahunka S (2001) Cave-dwelling oribatid mites from Greece (Acari: Oribatida) (Neue und interessante Milben aus dem Genfer Museum XLIX). Revue suisse de zoologie 108(1): $165-188$.

Mahunka S, Mahunka-Papp L (1995) The oribatid species described by Berlese (Acari). Hungarian Natural History Museum, Budapest, 325 pp.

Norton RA, Behan-Pelletier VM (2009) Oribatida. Chapter 15. In: Krantz GW, Walter DE (Eds) A Manual of Acarology. Texas Tech University Press, Lubbock, 430-564.

Ohkubo N (2001) A revision of Oppiidae and its allies (Acarina: Oribatida) of Japan 1. Genus Lasiobelba. Journal of the Acarological Society of Japan 10(2): 97-109. doi: 10.2300/ acari.10.97

Pérez-Iñigo C (1986) Contribución al conocimiento de los oribátidos (Acari, Oribatei) de la Gomera (Islas Canarias). Eos 62: 187-208.

Sanyal AK (1992) Oribatid Mites (Acari). In: Ghosh AK (Ed) Fauna of West Bengal. Part 3 (Arachnida and Acari). Zoological Survey of India, 213-356.

Sellnick M (1924) Einige neue südamerikanische Damaeosoma Arten. (Acar. Oribat.). Beitr.

Tierk. 1: 85-89.

Subías LS (2004) Listado sistemático, sinonímico y biogeográfico de los ácaros oribátidos (Acariformes: Oribatida) del mundo (excepto fósiles). Graellsia 60 (número extraordinario): 3-305. [Online version accessed in February 2014: 577 pp.]

Subías LS, Balogh P (1989) Identification keys to the genera of Oppiidae Grandjean, 1951 (Acari: Oribatei). Acta Zoologica Academiae Scientiarum Hungaricae 35(3-4): 355-412. Vasiliu N, Ivan O (1995) Oribatid mites from Israel. In: Soil fauna of Israel, Editura Academiei Romane, Bucuresti, 69-86.

Vasiliu NA, Ivan O (2011) New oppiid species (Acari, Oribatida, Oppiidae) from Romanian caves. Trav. l'Inst. Spéol. "Émile Racovitza” 50: 3-14. 
Wallwork JA (1964) Some Oribatei (Acari: Cryptostigmata) from Tchad (1st. series). Rev. Zool. Bot. Afr. 70(3-4): 353-385.

Wallwork JA (1977) Acarina. Cryptostigmata. In: La faune terrestre de L'île de Sainte-Hélène (4eme partie). Mus. Roy. Afr. Centr., Terv., Belg. Ann., Ser. 8, Sci. Zool., 220: 189-257.

Wang H (1993) Three new species of oppiid mites from China (Oribatida: Oppiidae). Acta Arachnologica Sinica 2(2): 97-103.

Wen Z (1999) A new species oribatid mite of the genus Lasiobelba from China (Acari: Oribatida: Oppiidae). Acta Zootaxonomica Sinica 24(1): 46-48. 